\title{
ACTIVITIES OF THE DIVISION OF SURGERY OF THE HEAD, OFFICE OF THE SURGEON-GENERAL.
}

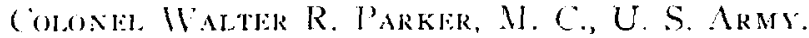

DHTROIT, MICIUAX.

This resume of the organization and work of the Division of Surgery of the Head in the Office of the Surgeon-General of the United States Army was read hefore the Section of Ophthalmology of the College of Physicians of Philadelphia, December 19, 1918. Authority to publish granterl, Board of Publicution, S. G. ().

In Nay 1917 the (ieneral Medical Board of the Council of National Defense at the suggestion of Dr. James Bordley Jr., appointed a subcommittee in ophthalmology and in August of the same year authorized a subcommittce in otolaryngology. The personnel of these committees was made up in part at least of members of the committees previously appointed by the special national socicties and special sections of the American Medical Association, at the refuest of the chairman of the General Medical Board of the Council of National Defense.

The personnel of each committee was as follows: Ophthalmology-Dr. James Bordley, Jr., chairman, Dr. George $\mathrm{F}$. de Schweinitz, Dr. Mllen Greenwood, Dr. Nelson M. Black, Dr. Walter R. Parker, Dr. W. H. Wilmer: Oto-laryngology-Dr. Char $\mathrm{l}$ es $\mathrm{W}$. Richardson, chairman, Dr. Harris ?'. Mosher, Dr. Burt R. Shurly. The work of the subcommittee of Ophthalmology began with the preparation of a catalog of the oplithalmologists of the country which included nearly nine thomsand names. To each name a questionnaire was mailed on June 13. 1917 and as a result over fourteen hundred signified their willingness to serve.

The subcommittee of Oto-laryngology later made a similar list of the otolaryngologists of the cotuntry and questionnaires were sent to fifty-six hundred oto-laryngologists.

Liter the two committees were contsolidated and a representative from the army and navy added, together with a representative of brain surgery and oral and plastic surgery. The per sonnel of the committee as finally constituted was as follqws: Dr. IVm. H.
Wilmer, chairman, Dr. Nelson $M$. Black, secretary, I)r. James Bordley, Ir., Dr. George E. de Schweinitz, Dr. Allen diecnwod, Dr. Walter R. Parker, Dr. Charles II. Richardson, Dr. Clarles Bagley, Jr, Dr. Harris 1'. Mosher, Capt. V. P. Blair, Major T. C. I.yster, M. C., U. S. Army, Surgeon G. F.. Trible, M C., U. S. Navy. The new members of the joint committee, viz: Dr. Chas. Bagley, Ir., representative of brain surgery and Capt. V. P. Blair representative of plastic and oral surgery, proceeded by means of questionmaires signed by their respective committees, to classily the surgeons in the comntry who were qualified as brain or plastic and oral surgeons.

The Surgeon General of the Army haul been kept in close touch with all phases of the development of the work of these committees and had determined upon the establishment of a division of surgery of the head in his office to be under the charge of Major T. C. I.yster. This plan was anthorized July 9, 1917, and quarters in the Surgeon (icneral's office were assigned and upened with the following personnel. Major T. C. I.yster, chief of the division, Major Nelson M. Black, in charge of Ophthalmology, Major Harris $I$. Mosher, in charge of Oto-laryngology, Capt. Chas Bagley, Jr., in charge of brain surgery, Capt. V. I. Blair in charge of Plastic and Oral surgery. The personnel thus formed in the surgeon general's office worked with the remaining members of the committee, who were on volunteer service in Washington, to secure personnel and develop the organization.

August 15, 1917, the Surgeon Gencral authorized the organization of a special head hospital of one thousand 
beds to be operated in connection with the hospitals of the A. E. F. Special committees were appointed to carry out these plans.

With the increased activities of the Division of Surgery of the llead in the surgeon (ieneral's ()ffice it became necessary to increase the persomnel of the organization, until finally is the last of September cvery member of the original comnittee of the Council was in uniform and all but three on duty in the Surgeon General's Office. Major James Bordley, Jr., was assigned to the Division of Reconstruction, Major Wn. H. Wilmer to aviation, Major Burt R. Shurly was director of the Red Cross I-Iospital No. 36 which went to France early and is still functioning overseas. Three additional officers were added to the staff in the Suryeon Gencral's Office making the jersonnel of the Division as follows: Major T. C. Lyster, in charge of the division; Major Nelson M. Black, in charge of Ophthalmology; Major Harris $P$. Mosher, in charge of Otu-laryngology; Capt. Chas. Bagley, Jr., in charge of Brain Surgery; Capt. V. P. Blair, in charge of Plastic and Oral Surgery; Capt. Robert II. Ivy, assistant in Plastic and Oral Surgery; Major M. (r. Scelig, Assistant in Brain Surgery and in charge of publications; Capt. H. H. Kerr, Assistant in Brain Surgery; Major Walter R. Parker, assigned to the Section of Ophthalmology in charge of the construction of Special Head Hospital No. 115; Major Allen Greenwood, as igned to the Section of Ophthalmology with special duties in reference to the personnel of Special Hospital No. 115, Major George E. de Schweinitz, assigned tu the Section of Ophthalmology in charge of equipment of Special Hospital No. 115 and especial publications. Later Major Kerr was assigned overscas and Capt. (now Major), Grover C. Pemberty, was assigned Assistant in Brain Surgery.

Major, now Brigadier General, Lyster, in company with Major, (now Lt. Colonel) de Schweinitz and Major, (now Lt. Colonel) Mosher, made a tour of inspection abroad. During the absence of this committee Major. (now
Colonel), Walter R. Parker was placed temporarily in charge of the Division of Surgery of the Head and later was made Officer in Charge. Later Major Blair went overseas and Captain, (now Major), Ivy was left in charge of Plastic and Oral Surgery. Still later Major Iry went overseas and Major G. V. I. Brown was assigned to his cluties.

In the Section of Ophthalmology Major Greenwood went overseas in charge of the Optica! Unit. Licut. Colonel Nelson M. Black soon joined him and when he left the office Lient. Colonel de Schweinitz was put in charge of Ophthalmology and Major William E. Bruner was assigned to duty in the Surgeon Gencral's Office in conncetion with Ophthalmology.

During Major Mosher's absence abroad Major Charles W. Richardson was put in charge of Oto-laryngology and later Captain Harry $\Lambda$. Barnes was made assistant in this section.

In addition to classifying the officers avatiable for scrvice, the activities of the division consisted in the selection and standardization of equipment, the preparation of a course of instruction in the base hospitals, organization of special schools and laboratories, assisting in the revision of requirements of registrants, the publication of manuals and periodicals and the recommendation of assignments for overseas duty.

Under the head of equipment might be cnumerated the following activities: (1) Standardization of instruments and material; (2) Selection of instruments for base hospitals and for special hospital for surgery of the head (No. 115); (3) Selection of equipment of Optical Units: (4) Standardization of spectacle frames al size of lenses for military use; (5) Investigation of possibility of domestic production of glass for artificial eyes; (6) Standardization of an cfficient goggle for aviators.

Under the education activities were included: (1) An outline of the course of lectures to be given at the cantonment base hospitals and at the Medical Officers' Training Camps; (2) List of books for libraries at base hospitals: (3) The organization of the special schools at Ft. Oglethorpe; (4) The 
compilation and publication of the following books:

1. The Section of OphthalmologyManual of Ophthalmology-published by the Government Printing Office.

2. At the request of the Publishing Committee of the Council of National Defense, three members of the Section of Ophthalmology, Cols. Greenwood de Schweinitz and parker, prepared a Manual of Ophthalmic Military Surgery including chapters on Trachoma and Examination of Malingerers, puls. lished by Lea \& Febiger.

3. The Section of Brain Surgery prepared a book on War Surgery of the Nervous System published by the Government P'rinting Office.

4. The Section of Plastic and Oral Surgery revised Blair's book on Surgery and Diseases of the Mouth and Jaw.

5. The Section of Oto-laryngology prepared a Manual of War Surgery on Oto-laryngology.

6. Survey of Hearl Surgery. A monthly publication.

The following schools and laboratories were established:

1. Officers' 'School of Plastic and Oral Surgery, Northwestern University Dental Sichool, Chicago, Illinois.

2. 'Thomas W. Evans' Museum of Oral Surgery, University of Pennsylvania, I'hiladelphia, Pennsylvania.

3. The Neuro-surgical Schools in Chicago, Philadelphia and New York.

4. The Neuro-surgical, Plastic and Oral Surgical School of St. Loutis.

5. School for Medical officers at Ft. Oglethorpe.

6. The laboratory at Baltimore for the investigation of neuro-surgical problems.

7. The laboratory at Ann Arbor for the investigation of peripheral nerve lesions.
The school at Ft. Ogelthorpe was represented by each of the Divisions in the Surgeon General's Office including not only medicine, surgery and laboratory but also the Divisions of Special Surgery. The Department of Ophthalmology was organized by Lieut. Colonel de Scliweinitz.

The clinical activities incident to the return of injured soldiers led to the consideration of the appointment of consultants in the various sections of the Division of Heat Surgery.

The complete record of the activities of the four sections of the Division of Surgery of the Ilead would not be of interest at this time so I shall give in detail only those pertaining to the Section of Ophthalmology.

The total number of ophthalmologists sent to training camps, base hospitals in this comtry and overseas was seven hundred and fifty-nine. Of these, two hundred and cighty were assigned to foreign service. In addition to this number three hundred and sixty-seven were transferred to other service making the total of officers assigned by the Scction of Ophthalmology eleven hundred and twenty-six.

During the year several extensive inspection tours to stucly the work of the Division of Surgery of the Head in a large number of the hospitals of the cantonments of this country were made by I.t. Colonel Black, and less extensive similar tours by Major Harris P. Mosher. Major Allen Greenwood, Colonel Walter R. Parker and Lt. Col. (icorge E. de Scliweinitz. The work of I.t. Colonel Tyster and his committec overseas included an inspection of all the American base hospitals in operation at that time (from November 19, 1917 to January 31, 1918), three Red Cross hospitals, one Naval Base Hospital and a number of base and gencral hospiats in the British service and one French sector as well as the general and special hospitals in England, and

Note: Since reading this paper the following appointments were made Dec. 24, 1918: Consultant in Ophthalmology, Lt. Colonel $G$. $v$ de Scinweinitz; Consultant in Otolaryngology, Lt. Colonel Harris P. Mosher; Consultant in Plastic and Oral Surgery, Lt. Colonel V. P. Blair, and Consultant in Netro-Surgery, Major Charles H. Frazier. 
a study of the method of caring for l linaled soldiers in France and England was made by Lt. Col. de Schweinitz.

An claborate study of the trachoma question was made from all standpoints by Lt. Col. Black, which included the trachoma hospitals and concentration camps, to observe the work of the U. S. Public Health Scrvice in preventing the spread of discase. A standard test for the detection of malingers who feigned visual defects was compiled by Colonel Parker.

After the standardization of the spertacles to be worn by the soldiers was perfected by Major (now Colonel) Wilmer and his committee, a plan was perfected whereby glasses could be supplied through the Post Exchange at wholesale prices. Later this plan was changed and the government now furnishes the soldiers spectacles gratis.

To meet the demand for spectacles for soldiers overseas a central optical unit was established in Paris with fourteen auxiliary units to functionate as mobile supply stations. A central plant and eight units were taken to France by Major (now Lt. Colonel) Greenwood, who was afterwards made Senior Consultant in Ophthalmology of the A. E. F. and who now has with him as assistants L.t. Colonel Nelson M. Black and Lt. Colonel Gicorge Derby.

Pursuant to the authorization of the Surgcon General for the development of the base hospital particularly devoted to surgery of the head to be established in France, a special base hospital was organized at Cape May in Ficiuary, 1918, was called for overseas duty the 24th of May, 1918, and is now functioning in France with Lieut. Colonel E. C. Ellett as commanding officer and Captain Francis, of Buffalo, in sharge of ophthalmology.

The work of the various sections as it is zarried out in the base and gencral hospitals is more or less familiar to all. In closing I wish to speak especially of the complete spirit of cooperation of all who have bcen associated in this work and of the courtesy and consirleration extended to all by the Surgesi: General and his entire staff.

\title{
SCHOOL OF OPHTHALMOLOGY.
}

\section{Medical Officers Training Group.}

Camp Greenleaf, Ft. Oglethorpe, Ga.

\author{
Major Meyer WJener, M. C., U. S. Army. \\ U. S. GENERAL ILOSH'ITAI, NO. 11, CAPIE MAY, N. J.
}

This paper details the schedulc and actual work of the School of Ophthalmology, the organization and development of which was described by Lt. Col. G. E. de Schweinitz (A. J. O., v. 1, p. 817). Read before the College of Physicians of Philaclelphia, feb. 5(h, 1919. Authority to pulflish granted, Boart of Publication, S. (i. ().

The Army School of Ophthalmology was the outgrowth of plans laid out by our distinguished and able confrere, Lieut. Col. George li. de Schweinitz, who, after several trips to Camp Greenleaf and Ft. Oglethorpe, selected the site, equipment and finally the instructors to direct and develop the school.

I arrived at Camp Greenleaf under War Department orders on July 19 , 1918 , and started on my course of military training with no idea as to what work I was to do, or where I was to be assigned. On July 30, I was ordered to report for duty to Lieut. Col. de Schweinitz, as instructor in the school of Ophthalmology. The length of the course had already been determined by the proper authorities, to be four wecks, and the hours from 9 to $11: 30$ and $1: 30$ to 4 , daily, excepting Saturday, when the hours were limited from 9 to 11. Col. de Schweinitz thought from the beginning that the two hours Saturday morning could be taken up to best advantage with written and 